Abstracta Iranica Abstracta Iranica

Revue bibliographique pour le domaine irano-aryen

Volume 42-43 | 2021

Comptes rendus des publications de 2019-2020

\title{
Lévon Nordiguian, Jean-Claude Voisin, Marina Mattar. La Grande Guerre au Moyen-Orient. Antoine Poidebard sur les routes de Perse 1918
}

\section{Rémy Boucharlat}

\section{OpenEdition}

\section{Journals}

Édition électronique

URL : https://journals.openedition.org/abstractairanica/52878

DOI : 10.4000/abstractairanica. 52878

ISSN : 1961-960X

Éditeur :

CNRS (UMR 7528 Mondes iraniens et indiens), Éditions de l'IFRI

Référence électronique

Rémy Boucharlat, « Lévon Nordiguian, Jean-Claude Voisin, Marina Mattar. La Grande Guerre au MoyenOrient. Antoine Poidebard sur les routes de Perse 1918 ", Abstracta Iranica [En ligne], Volume 42-43 | 2021, document 1, mis en ligne le 30 juillet 2021, consulté le 14 décembre 2022. URL : http:// journals.openedition.org/abstractairanica/52878; DOI : https://doi.org/10.4000/abstractairanica. 52878

Ce document a été généré automatiquement le 14 décembre 2022.

Tous droits réservés 


\title{
Lévon Nordiguian, Jean-Claude Voisin, Marina Mattar. La Grande Guerre au Moyen-Orient. Antoine Poidebard sur les routes de Perse 1918
}

\author{
Rémy Boucharlat
}

\section{RÉFÉRENCE}

Lévon Nordiguian, Jean-Claude Voisin, avec la collaboration de Marina Mattar. La Grande Guerre au Moyen-Orient. Antoine Poidebard sur les routes de Perse 1918. Beyrouth : Presse de l'Université Saint-Joseph, 2020, 135 p., 275 photos n\&b de l'auteur (1918), et 39 photos couleur de J.-C. Voisin (2018).

1 Dans la Perse, prise malgré elle, dans la tourmente de la Grande guerre, le témoignage du Père jésuite Antoine Poidebard (1878-1955), officier français délégué dans une mission britannique, peut paraître anecdotique. Son périple de six mois en 1918 dans l'ouest de l'Iran, prévu de Baghdad-Kermanshah-Hamedan-Qazvin-Enzali-Bakou à Tiflis fut interrompu à Mianeh du fait des mouvements militaires de la jeune armée turque.

2 Au-delà des considérations du militaire sur les forces alliées comme sur les ennemis, le regard de Poidebard sur les villes et villages, mais surtout sur les Persans et les minorités (il connaît le turc et l'arménien), est à la fois lucide et plein d'empathie. Dans deux petits carnets pleins de précisions et par des centaines de clichés, pris avec un appareil photo assez simple, il rend compte de la condition misérable des populations, et souvent de la famine qui règne dans l'ouest de l'Iran, et du désordre due à l'absence du pouvoir politique central. Les nombreux extraits des textes de Poidebard et ses photos que donne ce livre sont des documents précieux sur une autre facette de la guerre qui atteint indirectement des populations qui étaient en principe en dehors du conflit. 
3 Les archives photographiques de A. Poidebard sur cette période, comme une grande partie de son œuvre d'archéologue pionnier de la photographie aérienne au Levant, sont conservées à la photothèque de la Bibliothèque orientale de l'Université SaintJoseph de Beyrouth.

\section{AUTEURS}

\section{RÉMY BOUCHARLAT}

UMR 5133 CNRS-Université de Lyon 